\title{
Indicators of Rainforest Recovery from Disturbance
}

\author{
Ian Douglas
}

\author{
School of Environment, Education and Development \\ University of Manchester \\ Manchester \\ M13 9PL \\ UK
}

\section{ian.douglas@manchester.ac.uk}

\begin{abstract}
Recovery of forest after logging can be tested in many ways: the presence of particular species of fauna or flora, the similarity of the biodiversity of the recovering forest to that on neighbouring areas of undisturbed forest; or the characteristics of soils and streams whose conditions may have drastically changed during logging. Three cases of rainforest recovery after logging and clearance from Australia and Borneo exhibit different starting and different goals for recovery. Faunal indicators of recovery vary with size and with species dependence of the rainforest. Endemic forest species may have difficulty in recovering. Tree species richness and abundance may recover in two decades, but canopy closure takes longer. Compacted soils may retain low infiltration capacities for many decades. This diversity in recovery rates is confirmed when compared with those used elsewhere. Because the starting points for recovery vary, from damage by tropical cyclones and landslides, to clearance for shifting cultivation, pasture or agriculture, to post-logging conditions, universal indicators may be inappropriate. The desired endpoints of recovery also range from a "wilderness" state to a National Park for human enjoyment, biodiversity preservation, safeguarding rights of traditional forest-dwelling peoples, or a second round of selective logging.
\end{abstract}

\section{Keywords}

Rainforest, recovery, indicators, logging, grassland, shifting cultivation, forestry, national parks, traditional rights

\section{Introduction}

The sustainability of tropical forest management practices has long been discussed in terms of commercial forestry. In 1999, the International Tropical Timber Organisation defined sustainable forest management as: "The process of managing forest to achieve one or more clearly specified objectives of management with regard to the production of a continuous flow of desired forest products and services without undue reduction of its inherent values and future productivity and without undue undesirable effects on the physical and social environment" [1]. Sustaining the continuous flow of products and services implies many possible goals for forest sustainability, not merely the production of timber. Yet timber production itself involves forest recovery from previous harvesting, however intensive the logging process may have been. Thus, notions of rainforest recovery and its assessment are significant. 
Logging is not the only form of disturbance from which rainforests are recovering. Many have been affected by the wildfires in recent years, by volcanic eruptions, earthquakes and landslides. As well documented in Australia [2], Puerto Rico [3] and the Solomon Islands [4], many rainforests are regularly damaged by tropical cyclones (typhoons or hurricanes). Some them are hit so frequently that a distinct cyclone-rainforest type has been recognised. In such forests recovery is usually incomplete before another cyclone arrives.

In addition, rainforests are recovering from human disturbance for agriculture, grazing and traditional shifting cultivation (Fig. 1). Shifting cultivation requires a decade or so of recovery before another crop can be truly successful, but many shifting cultivators have access to insufficient land for such a recovery period and thus forest patches are cleared again after just a few years. Far longer term has been rainforest clearance for agriculture, which is still proceeding apace in several parts of the humid tropics. In some places now, agriculture has been reduced and rainforest is recovering or is being restored by tree-planting. This rainforest recovery is directed to diverse future states or uses.

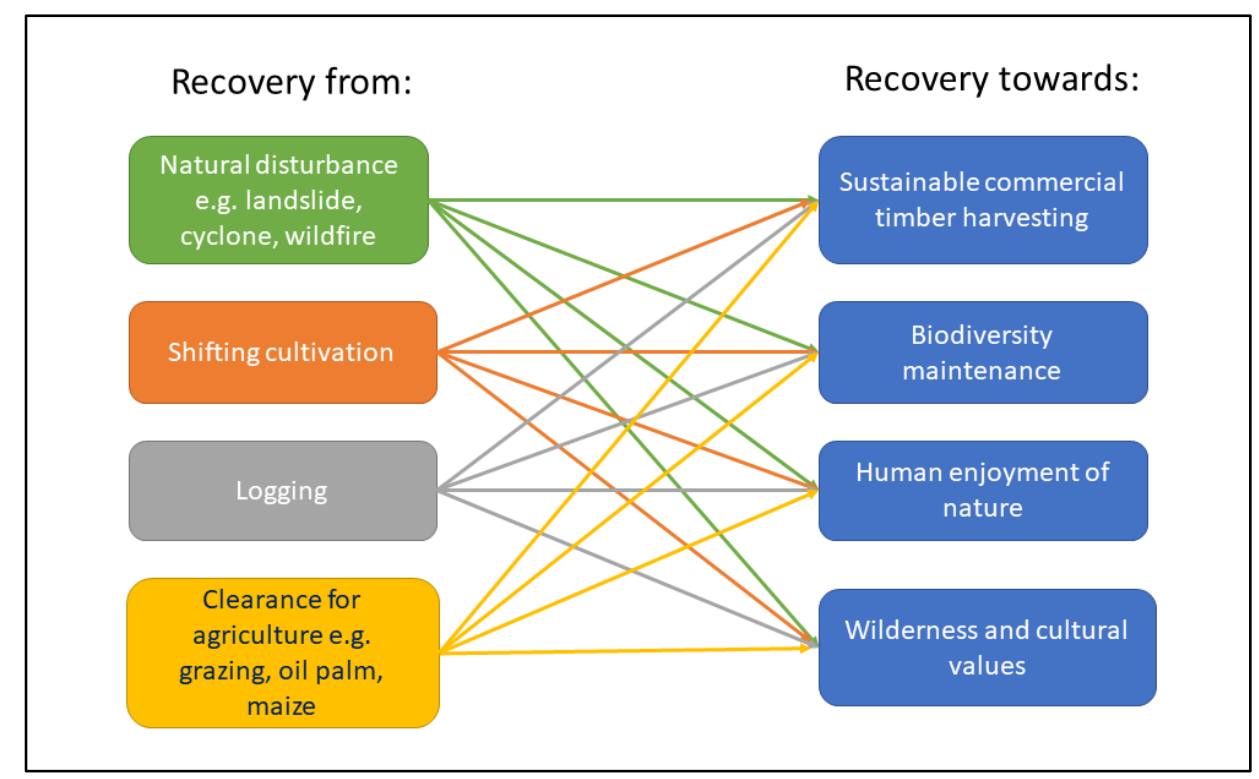

Fig.1. Pathways for rainforest recovery from disturbance.

Recovery of forest after logging can be tested in many ways: the presence of particular species of fauna or flora, the similarity of the biodiversity of the recovering forest to that on neighbouring areas of undisturbed forest; or the characteristics of soils and streams whose conditions may have drastically changed during logging. Diversity recovery in disturbed forests depends on disturbance intensity and frequency, forest size and reference conditions [5]. Lightly-logged areas might reach their original stage in relatively short time (20-50 years) as this logging intensity does not impair the underlying productivity [6]. However, intensivelylogged areas may well over a hundred years to reach later successional stages.

Rainforest recovery for biodiversity is often directed to sustain a particular species, such as gorillas or orang-utans. The management for such a goal for primates might emphasise the availability of fruit over other aspects of biodiversity. Much of modern rainforest protection is occurring in the context of broader goals that are strategically focussed on conservation, biodiversity, and environmental values. In Australia, much rainforest restoration has been related to these values, rather than to other priorities such as regional employment. Within these values, it may be appropriate to ask "Whose values?". For example, in the Wet Tropics of 
North Queensland Australia, there is a possible debate about the differing impacts of new National Park designations on the Aboriginal traditional inhabitants; on the local descendants the former famers and woodsmen who cleared the forest; and on the city-dwelling tourists who visit the area to "experience the rainforest". Hence the suggestion of "human enjoyment nature" and "wilderness and cultural values" as different, but overlapping, recovery goals in Fig.1.

This double diversity of the starting points of rainforest recovery and its goals raises question of how we should assess recovery. Harvestable timber availability would critical for a logging company. Adequate fruit accessible fruit sources are essential for an orang-utan. Visitors might not be as concerned about species diversity and tree growth dimensions, as about the closed canopy, the sound of the birds, the presence lianas and epiphytes, and clear water cascading over boulders. For the wilderness goal, recovery to the state implied by the term "wilderness" might be difficult. The definition used in Australia in the 1970's [7]: "wilderness is a large area of land perceived to be natural, where genetic diversity and natural cycles remain essentially unaltered", leaves scope to interpret the word "perception" because areas that had been disturbed 100 years ago might have recovered to a state that it seems to most people to be wild. Here it should be recalled that in the Amazon rainforest there are the remains of ancient cities beneath the wilderness [8]. Many areas now perceived to be, or are managed as, "wilderness" had previous disturbance by colonists, resource exploiters and hunters, as well as having been the homes of first nations peoples for centuries. So, recovery might well aim at recreating the opportunity to experience wilderness. Yet, there remains the question as to whether the traditional hunting and gathering practices of first nations peoples ought also to be permitted in protected wilderness: they were there long before most of us. I seek answers to the question of how should the recovery of a rainforest by judged? What are the appropriate indicators?

\section{Methodology}

To explore this dilemma, I examine three cases of rainforest recovery after logging and clearance, two from Australia and one from Borneo, examining the timing and nature of logging and how post-logging recovery has been assessed. I then analyse some of the various indicators of forest recovery that have been used, assess the recovery periods so derived and examine the purposes for which the indicators may be usefully. Finally, I use some comparisons from other parts of the world to suggest how multiple indicators of recovery, from the presence of indicator species to the persistence of logging roads, might be used.

\section{Australian case studies}

The remarkable series of rainforest remnants and patches, largely on basalt-derived soils on the coastal uplands of Eastern Australia are now largely protected as two world heritage systems, the Gondwana Rainforests of Australia and the Wet Tropics of Queensland. The Gondwana forests contain the largest and most significant remaining stands of subtropical rainforest and Antarctic Beech (Nothofagus moorei) cool temperate rainforests in the world, the largest and most significant areas of warm temperate rainforest and one of only two remaining large areas of Araucarian rainforest in Australia. The North Queensland site comprises $8942 \mathrm{~km}^{2}$ of mostly tropical rainforest, stretching for $450 \mathrm{~km}$ along the northeast coast of Australia.

Within or adjoining these World Heritage areas are forested areas that were logged in the late nineteenth century and that were cleared for agriculture in the first decade of the twentieth century. Some of the logged areas are now parts of National Parks within the two World Heritage sites. Some of the formerly cleared areas have been recolonised by rainforest or have 
been deliberately regenerated to become potential rainforest environments. Many would claim that this forest regrowth and the post-logging protection of rainforest have guaranteed rainforest recovery. To examine such claims, two localities on basalt in Eastern Australia provide initial case studies of the areas of forest recovery: the wet temperate Gondwana rainforest of the Dorrigo Plateau in New South Wales and the regenerating Wet Tropics forests of the south-eastern part of the Atherton Tableland in north Queensland. Thinking about the future of these Australian forests, in 1975, I wrote:

"However, it is not known how much account is taken of this [ecological] knowledge when particular groups of people use the resources of the rain-forest ecosystem. Do the clearers of the forest, the shifting cultivators, the dairy farmers of the North Coast of New South Wales, the state foresters, and the wood-choppers, all view the rain-forest in the same light? When they make their assessments, do they have a full knowledge of the system they are examining? Many of these people may not even think of the rain-forest as an organic system, but rather as something natural which they do not understand [9].

\section{The Dorrigo wet temperate forest}

Located above the New England Escarpment, this area, $30^{\circ}$ South of the Equator, was long settled by the traditional owners of Australia who had Borra grounds at the western edge of the forest that mid-nineteenth century Europeans referred to as "dense scrub". That maze of trees, vines and epiphytes began to attract the attention of Europeans in 1857 when the valuable Red Cedar trees (Toona ciliata (syn. Cedrela toona)) were seen as an exploitable resource. The cedar getters moved eastward from the Bostobrick area, building access tracks in the dense warm temperate rainforest. Originally, the logs were taken inland, westwards to Armidale, by bullock wagons. For many years, a route to the coast was sought, but by the time the Dorrigo Mountain Road was opened in 1893, the Red Cedar accessible on the plateau had been logged out. However, forest clearing for farming expanded on the Dorrigo plateau itself

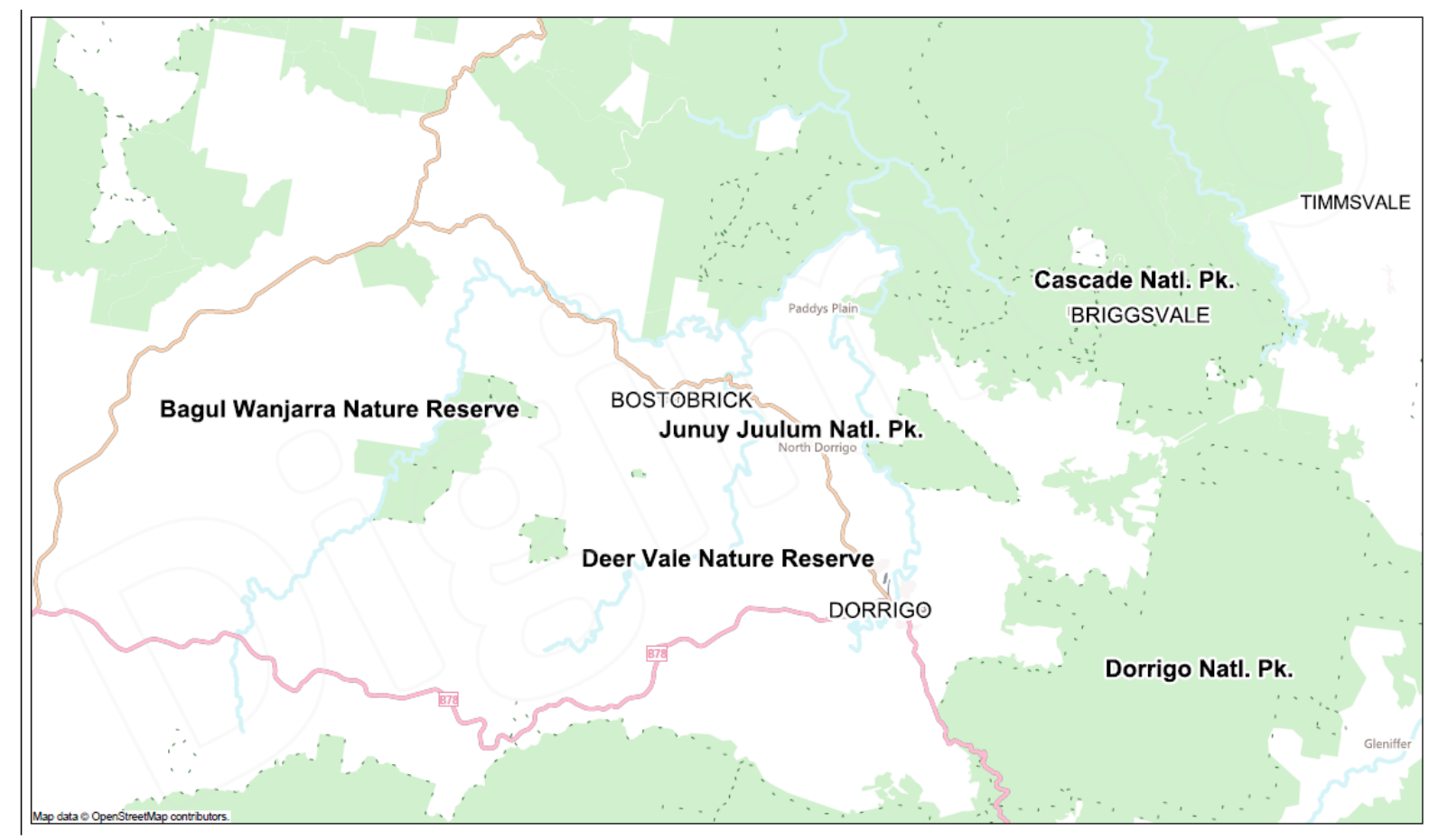


Fig.2. Map of the Dorrigo area to show the main areas of protected forest mentioned in the text (Contains information from OpenStreetMap, which is made available here under the Open Database License (ODbL)

Nevertheless, in 1901 the first 15 ha reservation of land for public recreation and preservation of native flora was created around Sherrard and Newell Falls, later to become the nucleus for what evolved into Dorrigo State Park in 1967. The area now contains the 7819 ha Dorrigo National Park and the 3700 ha Cascade and the 945 ha Junuy Juluum National Parks which also contain areas of wet temperate rainforest, dominated by coachwood (Ceratopetalum apetalum), crabapple (Schizomeria ovata) and booyong (Heritiera actinophylla), with smaller areas supporting hoop pine (Araucaria cunninghamii), Antarctic beech (Nothofagus moorei) and combinations of subtropical dominants.

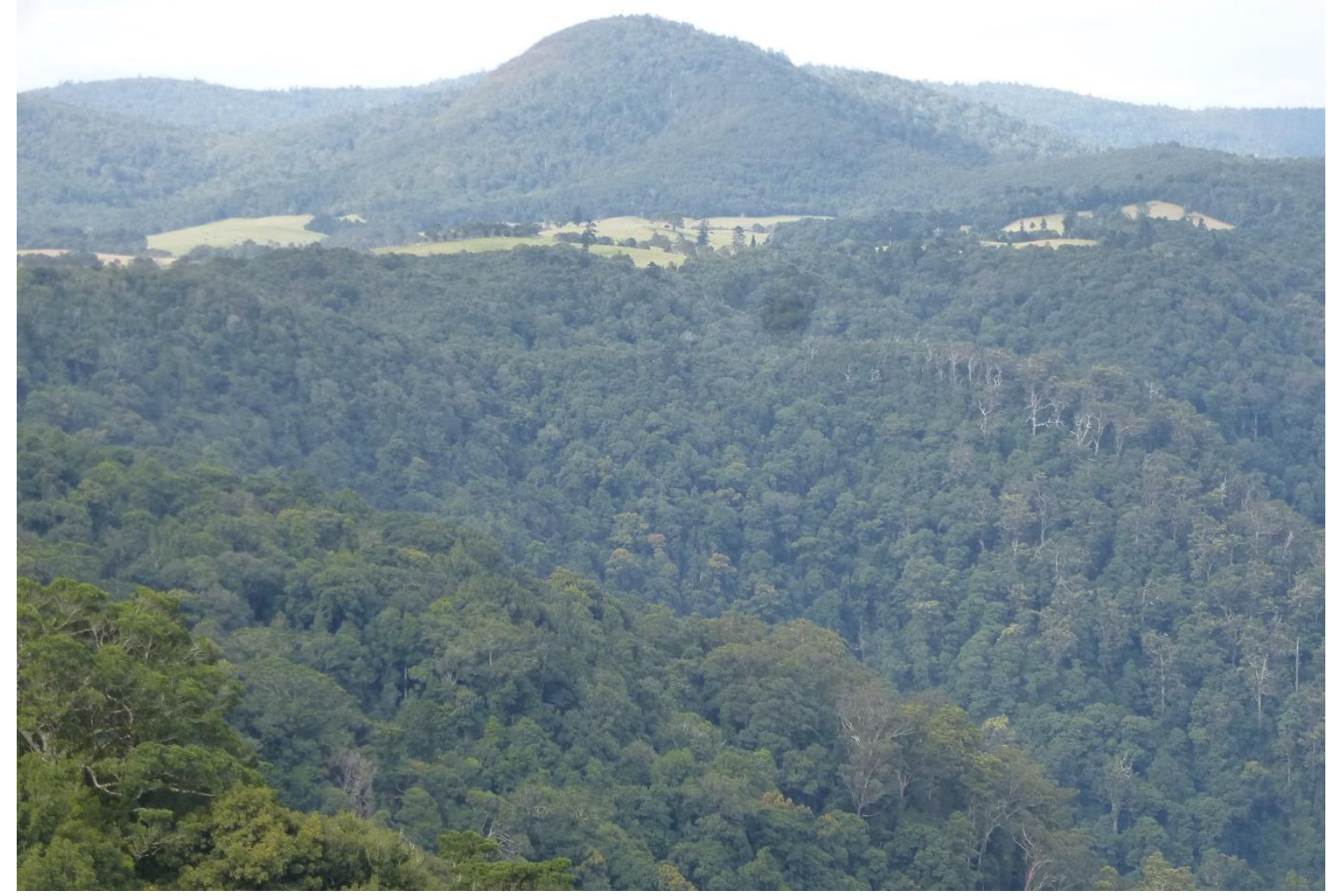

Fig. 3. The rainforests and cleared areas in and around the Dorrigo National Park in 2016

By 1925, all available timber from the Mount Campion area in the Junuy Juluum National Park had been taken and logging moved further north into the present area of the Cascade National Park, where remnants of tramlines used in the logging process are now seen as being of New South Wales state heritage significance. Elsewhere the remnants of an old cedar cutters' tracks, used to haul out logs, particularly red cedar, by bullock teams in the early $20^{\text {th }}$ century, can still be seen in the Deer Vale Nature Reserve. Timber extraction was significantly increased in the surrounding forests following the introduction of chainsaws in the early 1950s. Many forest 
compartments were re-logged at this time, with some logging of warm temperate rainforests continued until 1983.

By 2020, these areas had begun to have the appearance of old forests, abundant understorey plants conveying an impression of what the original "dense scrub" might have looked like. The author visited the then Dorrigo State Park in 1971 and saw the stumps of large trees where the notches for the planks on which the cross-cut saw operators stood to fell the Red Cedar were still visible. The recovery to the logged forest was clearly still in progress. Nearly 50 years later, the forest is less obviously a formerly logged area.

$15 \mathrm{~km}$ north of Dorrigo, a plot experiment to examine the recovery of warm temperate rainforest after logging, with differing removal rates of the tallest overstory trees, lead to estimates that these forests should have recovered early in the twenty-first century (Table 1). 
Table 1. Predicted time range for the recovery of the overstorey of the logged plots to the prelogging level of basal area (after [10])

\begin{tabular}{|c|c|c|c|}
\hline $\begin{array}{l}\text { Treatment (\% basal } \\
\text { area removed) }\end{array}$ & $\begin{array}{ll}\text { Reduction } & \text { in } \\
\text { prelogging } & \\
\text { overstorey } \% & \end{array}$ & $\begin{array}{l}\text { Predicted recovery } \\
\text { time range (years) }\end{array}$ & $\begin{array}{l}\text { Approximate } \\
\text { recovery time range }\end{array}$ \\
\hline 16 & 25 & $41-58$ & 1998-2115 \\
\hline 43 & 65 & 54-93 & $2011-2050$ \\
\hline 62 & 75 & $60-103$ & $2017-2060$ \\
\hline
\end{tabular}

Horne and Walter [10] predicted little change in the overstorey species, but considerable change in their relative numbers, coachwood being expected to increase its frequency fourfold, at the expense of crabapple and jackwood. They also forecast a reduction in the number of the largest trees of over $120 \mathrm{~cm}$ breast-height diameter (Dbh) which would indicate that the total basal area of trees after 80 to 100 years of recovery would still be less than that in the original forest (Table 2). This would mainly be due to the future dominance of coachwood, a tree that rarely exceeds $90 \mathrm{~cm}$ Dbh.

Table 2. Indicators of forest recovery used in the Dorrigo warm temperate rainforests and adjacent areas.

\begin{tabular}{|c|l|l|}
\hline Indicator type & Observations & Source \\
\hline Biodiversity & $\begin{array}{l}18 \text { species (three mammals, seven birds, seven reptiles and one frog) } \\
\text { less frequently detected in intensively logged than in unlogged areas } \\
\text { of NE NSW. Conversely, 33 species (3 mammals, 21 birds, 8 reptiles } \\
\text { and 1 frog) were found significantly more often in intensively logged } \\
\text { than in unlogged areas } \\
\text { In the Dorrigo area, the size of a forest fragment was the most } \\
\text { consistent predictor of mammal species richness in rainforest } \\
\text { remnants } \\
\text { Rodent abundance greatest in intermediate to smaller-sized forest } \\
\text { remnants. Possibly dense ground and understorey cover associated } \\
\text { with disturbance favours these rodents }\end{array}$ & [12] \\
\hline Frogs & $\begin{array}{l}\text { The tusked frog prefers areas of forest which have not been logged. } \\
\text { Two species of barred frogs will use breeding sites in logged forest, } \\
\text { but the giant barred frog prefers areas some years since last } \\
\text { disturbance. }\end{array}$ & [13] \\
\hline Avifauna & $\begin{array}{l}\text { Regrowth sites, with a substantially more rainforest-like vegetation } \\
\text { structure than pasture, supported about half the species richness of } \\
\text { rainforest-dependent birds found in intact rainforest sites }\end{array}$ & [14] \\
\hline Plants & $\begin{array}{l}\text { Basal area recovery after intense logging would take 60 to 103 years } \\
\text { Forest basal area recovery after intense logging would take 95 years }\end{array}$ & {$[$ [10] } \\
\hline
\end{tabular}

A later analysis of post-logging rainforest recovery of sub-tropical Complex Notophyll Vine Forest type in the Border Ranges National Park, at 28 $30^{\prime}$ 'South, over a 48-year period disturbance had promoted changes in tree diversity and dynamics [5]. Species showed the effects of disturbance through colonisation, adaptation, facilitation, and intraspecific and interspecific competition. At the end of the 48-year period there were distinctive boundaries between disturbed and undisturbed areas, with the disturbed areas having higher richness and tree density, as well as more pioneers and early secondaries than undisturbed areas (Table 3). The researchers suggested that 48 years was not enough time for a subtropical rainforest to recover as some logging impacts were still evident in disturbed areas, where stand basal area 
and tree diameters are lower, with more small trees, than in undisturbed areas (Table 2), and species dominance and floristic composition are yet to differ from original conditions. Earlier work in the same general areas suggested that if the rates of basal area increment over the 35 years since logging in the 1960s were to continue, projected achievement of initial basal areas would occur in the most intensely worked plots, 95 years after logging [15].

Table 3. Density and dynamics after 48 years for undisturbed and disturbed areas of subtropical rainforest in the Border Ranges, NSW (after [5]).

\begin{tabular}{|l|l|l|l|l|l|l|}
\hline $\begin{array}{l}\text { Treated area } \\
(1.08 \quad \text { ha } \\
\text { each })\end{array}$ & Richness & $\begin{array}{l}\text { Diversity } \\
\text { (Shannon) }\end{array}$ & $\begin{array}{l}\text { Diversity } \\
\text { (Berger- } \\
\text { Parker) }\end{array}$ & $\begin{array}{l}\text { Total } \\
\text { Basal } \\
\text { area } \\
\left(\mathrm{m}^{2} \mathrm{ha}^{-1}\right)\end{array}$ & $\begin{array}{l}\text { Tree } \\
\text { density } \\
\left(\text { stem ha }^{-1}\right)\end{array}$ & $\begin{array}{l}\text { Quadratic } \\
\text { mean } \\
\text { diameter } \\
(\mathrm{cm})\end{array}$ \\
\hline Undisturbed & 61 & $3.00 \pm 0.06$ & $0.20 \pm 0.020$ & 59.5 & 560 & 36.8 \\
\hline Disturbed & 71 & $3.16 \pm 0.06$ & $0.16 \pm 0.06$ & 39.5 & 722 & 26.4 \\
\hline
\end{tabular}

In the eastern Dorrigo plateau, using birds and plants as indicators, regrowth sites appeared to have developed a more rainforest-like vegetation than pasture, but they supported about half the species richness of intact rainforest sites [14]. The overall message is that forests regrow, but with a differing species composition and all regrowth areas lack some particularly rainforest- dependent species. Species abundance and richness assessments may indicate a general recovery in 30 to 50 years, but trees growth to the original canopy heights and basal area of the undisturbed forest may take over 100 years.

\section{The Atherton Tableland, North Queensland}

The Tableland was originally covered with wet tropical rainforest. Much of it was cleared during the first half of the twentieth century and now small patches of rainforest and reforestation now exist in a matrix of pasture-dominated agriculture. To the east, dense rainforest covers the ranges in the Gadgarra and Wooroonooram National Parks (Fig.4). The rainfall ranges from 1000 to $3000 \mathrm{~mm}$ per year, but the biggest storms, sometimes associated with tropical cyclones, occur between November and March, the southern hemisphere summer. 


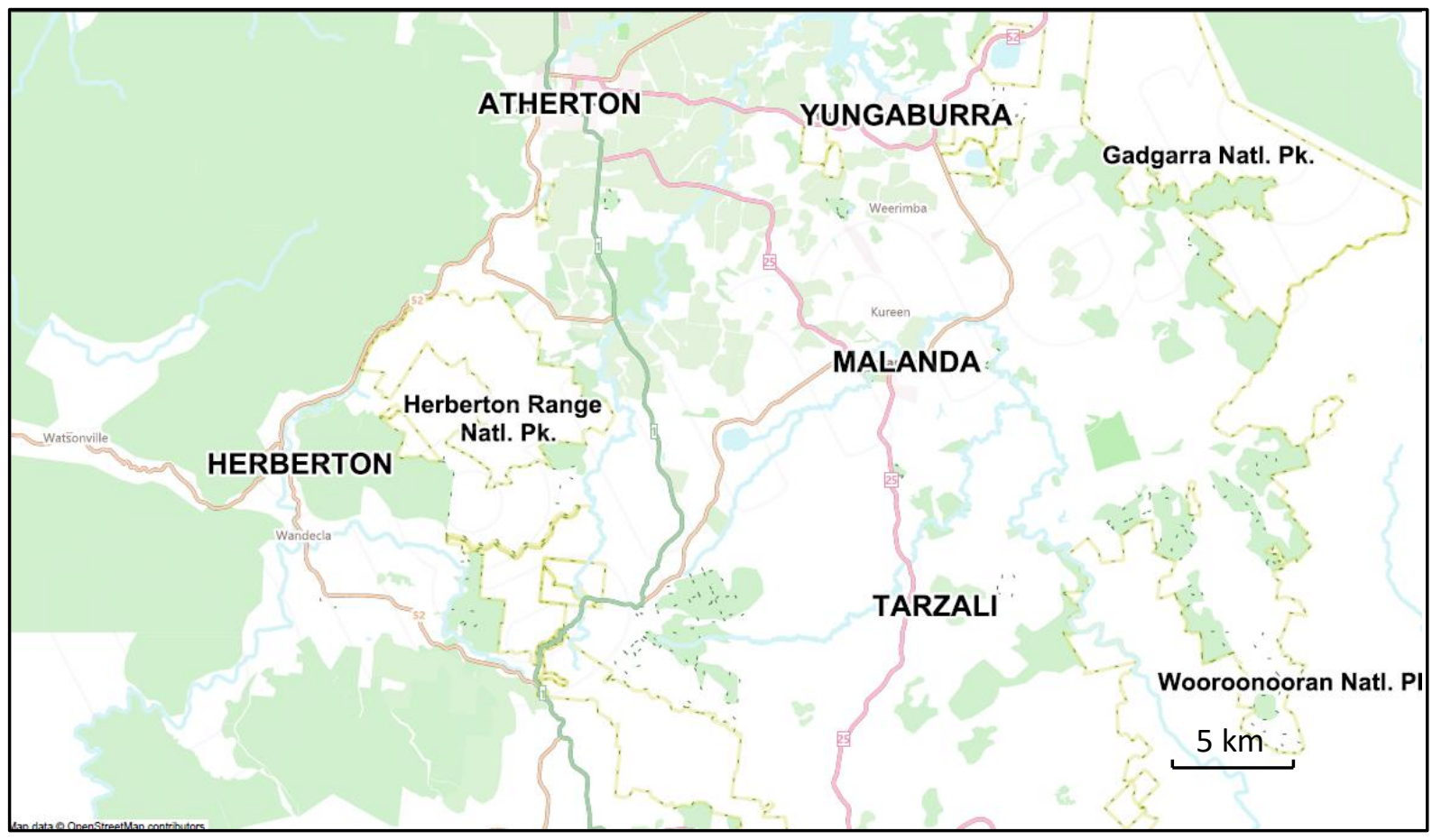

Fig.4. Map of the Atherton Tableland area showing the main National Parks and places mentioned in the text (Contains information from OpenStreetMap, which is made available here under the Open Database License (ODbL)

European people began to exploit the natural resources of the Atherton Tableland from the mining areas around Herberton (to the west of the Herberton Range national Park, Fig. 4 ) where mining for gold, silver and tin began in 1878. Some entrepreneurial miners moved east to cut red cedar, Toona ciliata, which was so highly prized at the time that it became known as "red gold" [16]. From the late 1800s, the rainforest on undulating country around Malanda began to be cleared for dairy farming, which subsequently became a prosperous local industry. Clearing continued into the 1960s leaving much of the landscape with few trees (Fig.5), but it supported some 600 dairy farms [17]. The dairy industry began to contract in the early 1970s, when subsidies were removed, and again from 2000 following industry deregulation, with only 51 dairy farms remaining in 2005 [18]. 


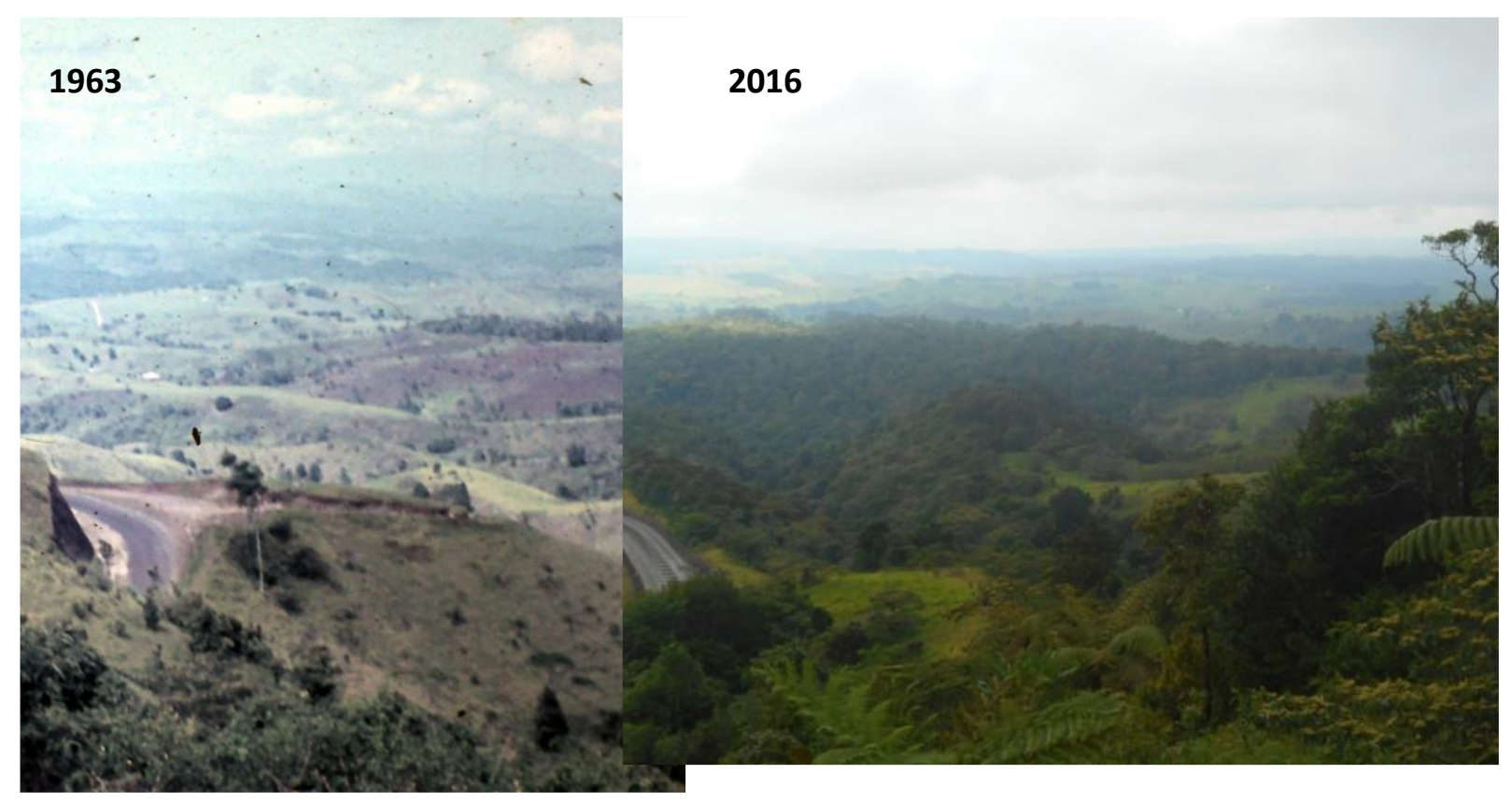

Fig. 5. Views over the southern Atherton Tableland towards Malanda from a high point near Tarzali in 1963 and 2016 showing the increase in forest cover (Photos by the author)

The Tablelands are now a mosaic of grasslands and patches of regenerating, or recovering rainforest of various sizes. Several efforts to replant or augment regeneration in forest patches have been made. The impact of these types of land cover change have been assessed in different ways, from the examination of ant communities to the assessment of the trees in forest stands.

As the 2016 photo in Fig. 5 shows, patches of trees tend to become larger close to large forested areas, regrowth being more rapid in spaces close to existing undisturbed forest [18]. Regrowth patches within $100 \mathrm{~m}$ of the old forest take around 11 years abandonment to achieve $70 \%$ successional canopy closure, while those up to $2500 \mathrm{~m}$ away from the forest require about 19 years [16]. Thus, canopy closure as an indicator of regrowth will vary spatially (Table 4). 
Table 4. Indicators of forest recovery used in the wet tropical rainforests of the Atherton Tablelands

\begin{tabular}{|c|l|l|}
\hline Indicator type & Observations & Source \\
\hline Biodiversity & & \\
\hline Beetles & $\begin{array}{l}\text { After 10 to 15 years, volant beetle assemblages in restoration sites } \\
\text { more similar to those of rainforest, and less similar to grassland }\end{array}$ & {$[19]$} \\
\hline Ants & $\begin{array}{l}\text { Ant assemblages in restoration sites had not fully reached a mature } \\
\text { forest state after 24 years }\end{array}$ & [20] \\
\hline Avifauna & $\begin{array}{l}\text { In all species, both total richness and total abundance in revegetated } \\
\text { sites had reached levels similar to those of forest about 5 years after } \\
\text { restoration planting }\end{array}$ & [21] \\
\hline Mammals & $\begin{array}{l}\text { Small mammal species richness, number of individuals, and species } \\
\text { diversity in recovering restored forest and undisturbed forest sites } \\
\text { similar to or less than grassland sites }\end{array}$ & [22] \\
\hline Plants & $\begin{array}{l}\text { Forest regrowth is more rapid close to existing undisturbed forest: 11 } \\
\text { years at 100 m away, 19 years at 2500 m away }\end{array}$ & {$[16]$} \\
\hline $\begin{array}{l}\text { Environmental factors } \\
\text { Soil }\end{array}$ & $\begin{array}{l}\text { Organic C and nutrients around 10 \% lower in grassland and in } \\
\text { secondary forest around 5\% lower than in undisturbed forest }\end{array}$ & [23] \\
\hline
\end{tabular}

Grassland ant species differ markedly from those in rainforest, species becoming became increasingly forest-like with increasing age of restoration (Figure 6) [20]. Ant assemblages in sites that have been regenerating for over 10 years are more like this in the rainforest than in grassland. However, ant assemblages in restoration sites, where planting had occurred, take more than 24 years to attain a mature forest state. Thus, rainforest recovery through restoration on the Atherton Tablelands might need at least 50 years to achieve quality faunal habitat approaching old-growth rainforest, with some taxa possibly requiring 100 or more years.

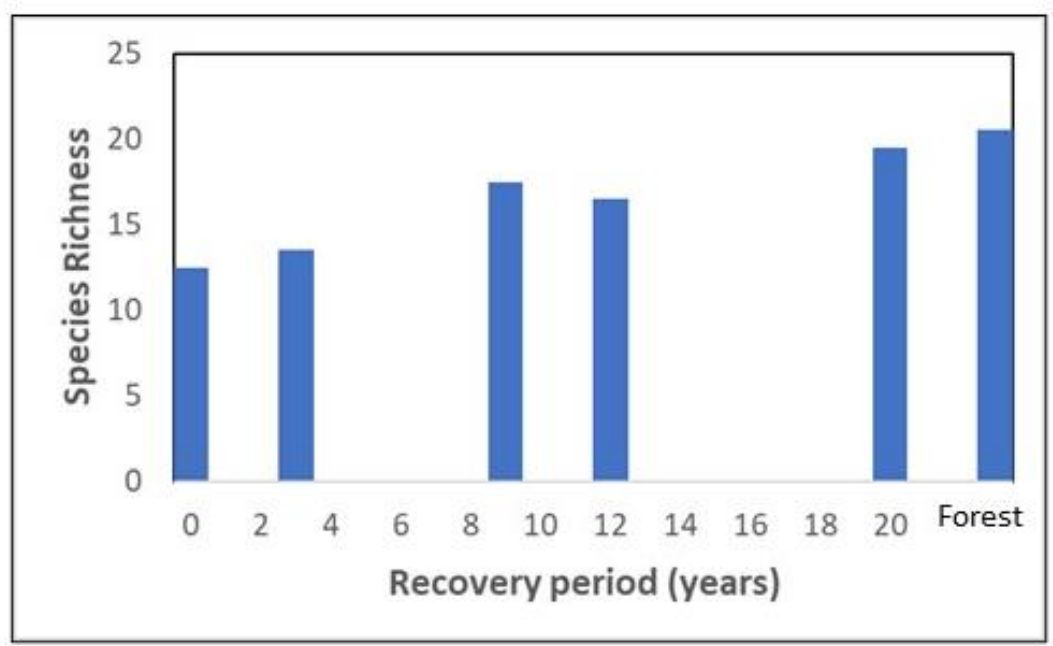

Fig. 6. Mean values of site species richness of ants found at sites at different stages of regeneration from grassland to rainforest in the Atherton Tableland (based on data from [20])

Beetle assemblages in rainforest patches on the Atherton Tablelands are high in numbers of individuals and species, with far fewer beetles occurring in grassland. Even though it takes a 
long time for the forest structure to recover, the volant beetle assemblages in restoration sites become more similar to those of rainforest within 10 to 15 years [19]. Overall beetle abundance is unaffected by distance, but isolated recovering rainforest patches can slow to achieve a rainforest-like beetle species composition.

Both total richness and total abundance of bird species in restoration sites became similar to those of forest after about 5 years (Fig. 7). However, a predictable subset of bird species that returns more slowly to regrowing forest restoration, even when replanting speeds up canopy cover development. These later-returners are usually endemic species of special conservation concern that depend upon the wet tropical rainforest. This is part of global trend for rangerestricted tropical rainforest bird species to be less able tolerate habitat disturbance than other forest birds. Thus, the restored rainforest may not recover the full range of species that are unique to that region's forests [21].
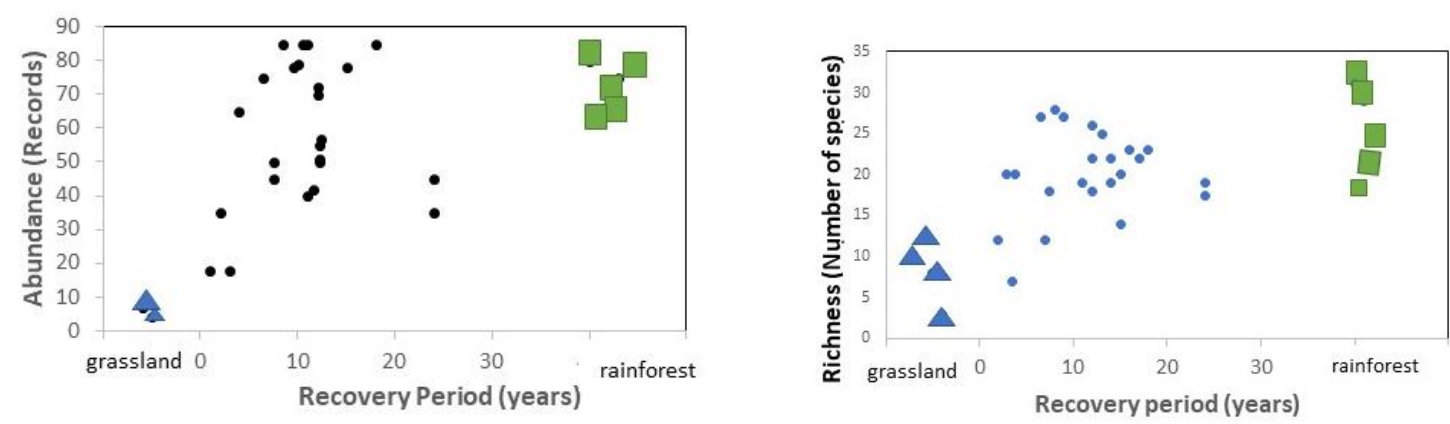

Fig. 7. Bird abundance (number of records) and richness (number of species) in grassland and revegetated sites 1 to 24 years into recovery on the Atherton Tablelands (based on data in [21]).

In this case, there is a predictable subset of species that is slower in returning during forest restoration, even when replanting is used to speed up the development of canopy cover. There later-returners are usually species of special conservation concern that are Wet Tropics rainforest-dependent endemic species. This reflects a global trend that range-restricted tropical rainforest bird species are less able to tolerate habitat disturbance than other species in a region's forests. Thus, the restored rainforest may be least effective in providing the habitat capable of attracting the very bird species it needs the most [21].

Small mammal species richness, number of individuals, and species diversity in the restored and undisturbed Atherton Tableland rainforest sites are similar to or lower than in grassland sites [22]. As restoration sites recover, they achieve higher biomass productivity and begin to support larger-bodied mammal species typically found in mature rainforests. The shift from pasture-like to more rainforest-like mammal communities begins about 5 years after planting, when canopy closure begins to occur.

Soil conditions can inhibit forest recovery, with organic carbon and nutrients in grassland, secondary forest and undisturbed forest varying in differing ways with land cover. Organic carbon and nitrogen are 5 to $15 \%$ lower under grassland than under forest, with levels in recovering forest being between these extremes. Calcium varied in a similar fashion on the basalt soils, while phosphorus did not vary at all [25]. These variations in soils and species numbers with sites, distance and age reveal complexity in the manner in which counts of certain species can be indicators of rainforest recovery from disturbance. The rain forest specialist and 
endemic species may be the best indicators for biodiversity recovery, but their absence may not spoil people's enjoyment of the rainforest.

\section{Ulu Segama, Sabah, Malaysian Borneo}

The highly valuable and effective expansion of ecological work in Ulu Segama area of eastern Sabah, since 1985 has brought about great knowledge of individual aspects of forest recovery from selective logging [26, 27]. The previously untouched rainforest east of the S. Segama (Segama River) and north of the Palam Tambun catchment (Fig. 8) was selectively logged in 1988-93. The area west of the S. Segama has remained unlogged lowland Dipterocarp forest and acts as control against which the impacts of, and recovery from, logging may be assessed. There is information on how different taxa respond to disturbance and how species numbers and richness change. Data have been gathered on how disturbed areas continue to erode during extreme events and the time taken for logging-induced landslides to recover. Several ecological studies have examined recovery of the forest vegetation and of particular animal communities.

In this environment, as in most tropical rainforests, the undisturbed forest is undergoing continual change. Natural gaps, created by treefall or landslides, become revegetated with rapidly growing light-loving, pioneer species, followed by many saplings, so that quickly there is a small, but dense clump of pole-sized $(2-15 \mathrm{~cm}$ Dbh) trees. Elsewhere there can be groups of tall mature dipterocarp trees of $70 \mathrm{~cm}$ or more Dbh with a highly open understorey between them. In a way therefore, a selectively logged forest is like an undisturbed forest with enormous gaps that are quickly invaded by pioneer seeds and by whatever emerges from the seed bank left between the zone of compacted ground. This hard ground disperses water as surface runoff into rills and gullies washing fine plant material and soil particles away, making seedling development difficult. The recovering forest becomes a habitat mosaic in which some species quickly find niches and others become rare, as habitats like old trees with holes will have disappeared. Fortunately, data are available for varied animal and plant species, and for aspects of the physical environment that indicate a range of recovery rates. 


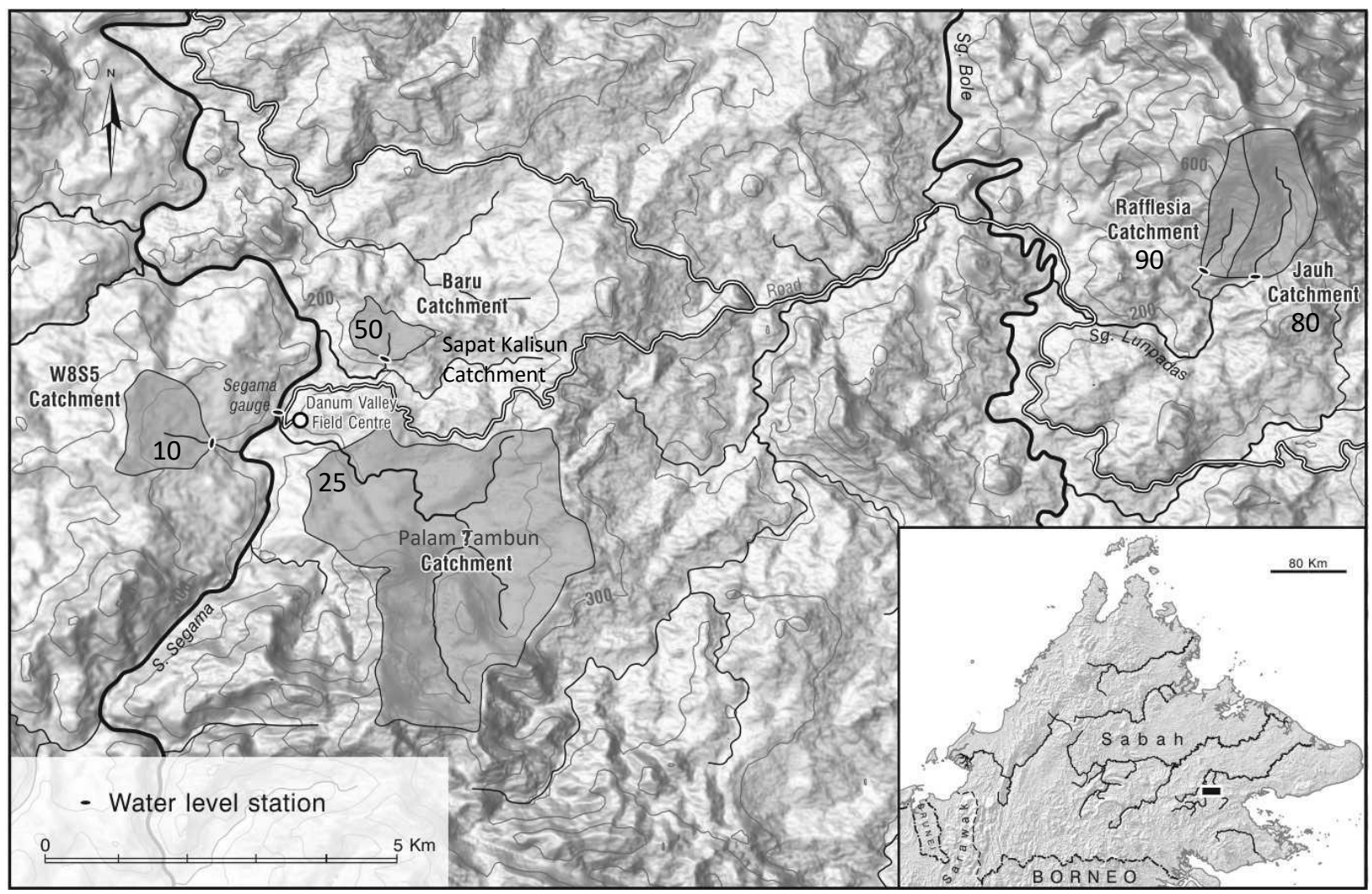

Fig. 8. Map of the hydrological study catchments and water level recorder sites being used at Danum Valley, Ulu Segama, as operating in 1992 to monitor the impacts of logging.

Both forest structure and community composition were affected by selective logging, despite there being little significant difference in richness or diversity. Total stem basal area and stem density were higher in unlogged forest than in naturally regenerating logged forest, driven by greater density of pole-sized trees $(2-15 \mathrm{~cm} \mathrm{dbh})$. In logged forest, sapling and pole stem density increased with time after logging, while in naturally regenerating forest, stem density was greater but did not increase over time. Tree community composition differed significantly between unlogged and naturally regenerating logged forest. In logged forest, there was no effect of active restoration (conducted 12-24 years pre-census) or time since logging on the overall community composition, however several individual species were indicators of the active restoration treatment. Together, our results suggest that the effects of selective logging on tree communities can still be observed 23-35 years after harvesting regardless of active restoration efforts.

While richness and diversity are shown to be approximately equivalent to pre-logging values within 35 years post-logging, community composition remains distinct from nearby unlogged forest with no detectable directional shifts at the decadal time-scale. As a result, it is unlikely that selective logging cycles of 40-60 years will be successful in balancing economic management of Sabah's forests with long-term tree species conservation. Furthermore, although active restoration efforts in Danum Valley may have had positive impacts on mean stem size and therefore aboveground biomass, they did appear to affect tree community composition, richness, or diversity by comparison with naturally regenerating plots for plots censused 12-24 years after the start of the intervention [28].

Long-term (21-30 year) erosional responses of rainforest terrain in the Ulu Segama catchment, Sabah, to selective logging may be assessed at slope, small and large catchment scales. In the 
$0.44 \mathrm{~km}^{2}$ Baru catchment, slope erosion measurements over 1990-2010 and sediment fingerprinting indicate that sediment sources 21 years after logging in 1989 are mainly roadlinked, including fresh landslips and gullying of scars and toe deposits of 1994-1996 landslides. Most of the disturbed slopes and former log landing areas had become revegetated, so acquiring a good litter layer. The 5 to 15 - minute interval sediment and water discharge indicate that sediment delivery from storms decreased from1996 to 2009 but may not have fallen to pre-logging levels. Annual yields for 2003, 2004 and 2005 were 395, 74 and $52 \mathrm{t} \mathrm{km}^{2}$ $\mathrm{y}^{-}$respectively [29] which may be compared with yields of $117 \mathrm{t} \mathrm{km}^{2} \mathrm{y}^{-1}$ in both 1989 and 1990 from the undisturbed W8S5 catchment. The markedly high sediment load of 2003, and the later high load in 2009, have been linked to high frequencies of rainstorms of the range 50-120 mm in size, rather than more extreme events [30].

Analysis of bed-sediment geochemistry indicates that $49 \%$ of the $216 \mathrm{t} \mathrm{km}^{2} \mathrm{y}^{-1}$ sediment yield in 2009 came from the $10 \%$ of its area affected by road-linked landslides. Recovery is clearly a slow process, but not dissimilar to recovery rates based on bulk density estimated for logged areas elsewhere in Malaysia (Fig. 9.). The persistence of these mass movements derived from road construction suggests that post-logging treatment of abandoned road would greatly help forest recovery, enhance aquatic ecosystems and reduce downstream sediment problems. These compacted areas persist, particularly on roads and skid trails. The latter also continue to have unfavourable tree growth conditions 18 years after logging (Table 5). While after twenty years or so, in many ways the logged forest resembles the undisturbed forest, although lacking mature trees, key areas, such as some skid trails and most abandoned roads, show little or no recovery. High bulk densities of compacted soils persist for decades (Fig. 9.).

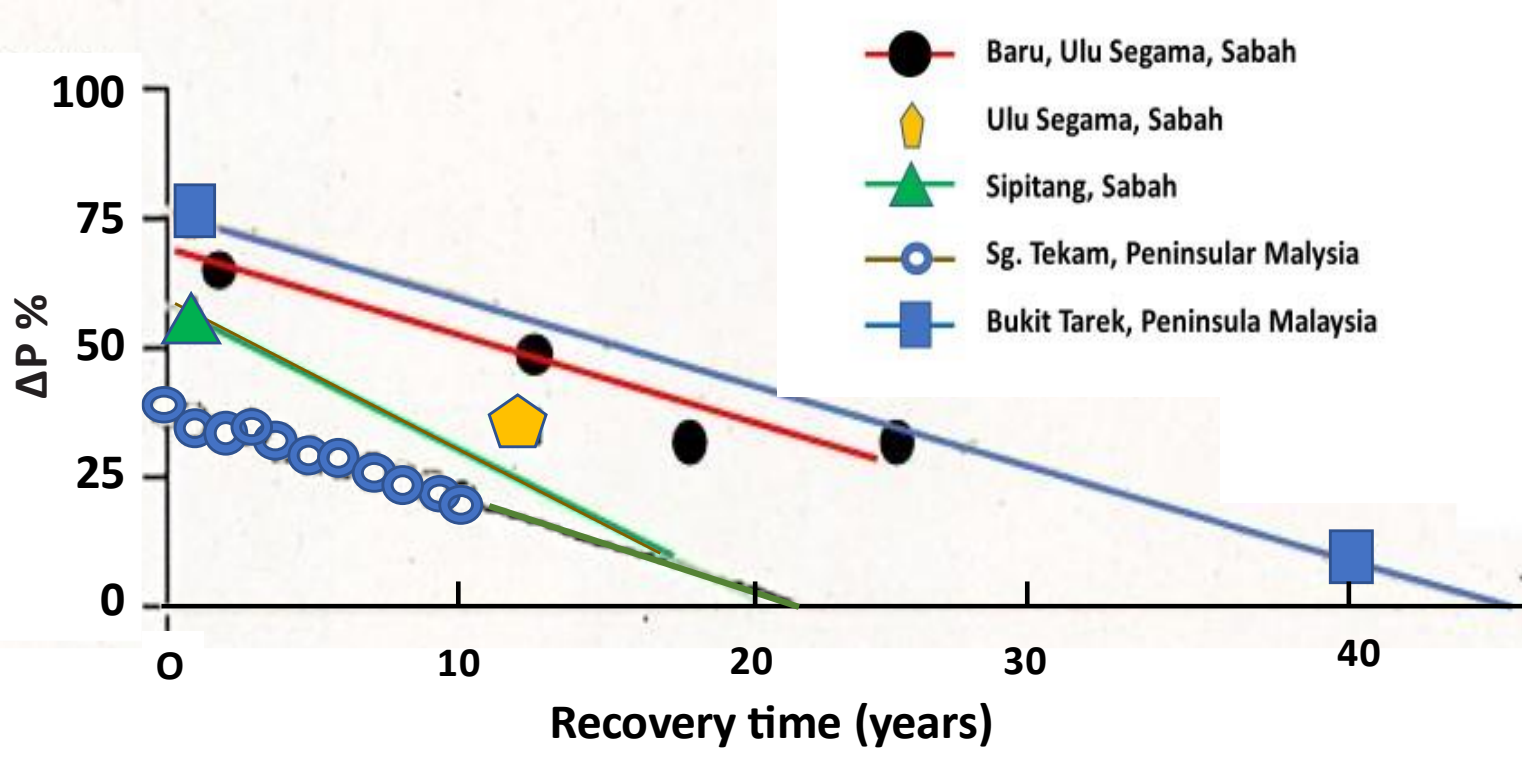

Fig. 9. Percentage changes $(\Delta \mathrm{P})$ in bulk density over time relative to undisturbed lands, are shown for abandoned skid trails at Sg. Tekam [31], mechanized logging tracks at Sipitang [32], logging tracks in the Ulu Segama [33], an abandoned skid trail in the Bukit Tarek catchment [34] and the abandoned skid trail at near Site 50 (Fig. 8). The symbols represent measurements. The lines track the estimated recovery in the soil property over time; full recovery occurs where lines cross the $\mathrm{x}$-axis at zero (from data and ideas in [34]). 
Calculation of the percentage change in bulk density $(\Delta \mathrm{P})$ : $\Delta P=\frac{P_{\text {disturbed }}-P_{\text {control }}}{P_{\text {control }}} \times 100 \%$

Table 5. Biodiversity and environmental indicators of forest recovery after logging at Danum Valley

\begin{tabular}{|c|c|c|}
\hline Indicator type & Observations & Source \\
\hline $\begin{array}{l}\text { Biodiversity } \\
\text { Animals }\end{array}$ & $\begin{array}{l}\text { High species richness in logged forest due to invasions of generalist } \\
\text { species } \\
\text { Logging results in a significant shift in species adaption for birds, } \\
\text { scavengers, ants and dung beetles }\end{array}$ & [35] \\
\hline Dung beetles & Lower observed species richness in logged forest & [35] \\
\hline Leaf litter ants & Trophic structure difference and abundance $30 \%$ lower in logged forest & [36] \\
\hline True bugs & Strong predictor of logging impacts on species & [35] \\
\hline Springtails & Do not decline as much after logging as other species & [37] \\
\hline Avifauna & $\begin{array}{l}\text { Particular species affected differently: fewer hollow (cavity) nesting birds } \\
\text { in the logged forest } \\
\text { Alterations to trophic organisation and interactions among species, may } \\
\text { be an important and hidden effect of forest degradation }\end{array}$ & [38] \\
\hline Mammals & $\begin{array}{l}\text { Small species (e.g. Leopoldalmys and Maxomys) generally more } \\
\text { abundant in logged forest than in primary forest }\end{array}$ & [35] \\
\hline Plants & $\begin{array}{l}\text { Up to } 18 \text { years after logging, species richness and stem density of woody } \\
\text { plants is lower on former skid trails than in adjacent forest } \\
\text { Pioneer tree saplings relatively abundant on skid trails three years after } \\
\text { logging. } \\
\text { Conditions for tree regeneration are similar on all skid trails up to } 18 \\
\text { years after logging } \\
\text { After } 18 \text { years the skid trail coarse root mat was only } 12 \% \text { of the pre- } \\
\text { logging level }\end{array}$ & [39] \\
\hline $\begin{array}{l}\text { Environmental } \\
\text { factors } \\
\text { Climate }\end{array}$ & $\begin{array}{l}\text { Selective logging had little impact on absolute microclimatic temperature } \\
\text { or its daily variation }\end{array}$ & [40] \\
\hline Soil & $\begin{array}{l}\text { Bulk density trends of compacted soils remained high } 24 \text { years after } \\
\text { logging at Danum (Fig. 8.) as in other places in Malaysia }\end{array}$ & \\
\hline Sediment & $\begin{array}{l}\text { Fingerprinting through radiometric dating of sediment showed the } \\
\text { effects the } 1992-3 \text { steep slope logging in the Segama catchment } \\
\text { Fingerprinting offers possibility of dating sequences of flood deposits and } \\
\text { the sources of their sediment }\end{array}$ & {$[30]$} \\
\hline
\end{tabular}

So, two key questions emerge: "How should we gauge forest recovery? What indicators should we use?" The potential indicators (Table 5.) vary greatly in what they tell us. Further thought should be given to this when mitigation methods are considered, particularly to indicators relating to skid trails and logging roads.

At Danum, 18 years after logging, the species composition of logged forest differed considerably from unlogged forest. There are more dipterocarps in logged than in unlogged forest; but the unlogged forest had more dipterocarps above harvestable size. However, polesize dipterocarps in the logged forest understorey show that trees of commercial species are in the recovering forest, which would mean the resources for future timber harvesting could be there in future. Reduced impact logging (RIL) areas retained a higher number of bird species, 
but a lower number of ant and dung beetle species than conventionally logged areas. RIL techniques greatly reduced canopy damage [43] but the impacts on soil are less clear.

Overall, the many investigations at Danum concluded that all forms of logging are harmful to some species, but that logged forests nevertheless retain very high levels of biodiversity [44]. Choosing animal species as indicators of forest recovery may be difficult. Tree regrowth, canopy closure and canopy height appear to be more robust indicators, especially in terms of timber resources. But the work Danum clearly demonstrated that the persistence of both logging infrastructure, especially compacted soils, and landslides related to collapse of that infrastructure is likely to restrict recovery of small patches and the linear gaps along routes wthin logged forests, just as the evidence of logging installations made 100 years ago is still apparent in the Dorrigo forests.

\section{Potential recovery indicators from forests elsewhere}

\section{Woody species recovery}

Several examples from the Brazilian Atlantic Forest and Amazonian forests demonstrate the use of tree species as indicators of recovery, with average recoveries of $70 \%$ of species richness, but only $25 \%$ of species composition. Stand age and environmental drivers (i.e., soil properties) appear to determine species diversity during succession. In the Atlantic Forest, where secondary forests are dominated by fast-growing and wood-producing species, with a rapid increase in timber stocks in the early stages of succession, commercial species represent about 51 percent of tree diversity. Such commercial species over $15 \mathrm{~cm}$ in diameter appear after 20 years of regrowth, with trees over $30 \mathrm{~cm} 10$ years later [45, 46].

In the rainforest at the Central African Republic's M'Baïki experimental site, despite high losses of forest above ground biomass from timber extraction, thinning and associated damage, $63 \%$ of disturbed experimental plots had recovered to the original biomass 24 years later and $85 \%$ were expected to recover it within 30 years [47]. Such high recovery rates observed in M'Baiki contrast with observations elsewhere in African forests, where the basal area may require more than 100 years to recover. Differences might be explained by a combination of factors: higher soil fertility, presence of a large pool of pioneers - comprising the very fast growing Musanga cecropioides R. Br. (Urticaceae), absence of invading climbers, lianas, shrubs or herbs able to arrest succession, absence of elephants and other ground-dwelling animals able to delay succession, as a result of intense hunting by local villagers, and limited soil damage from logging operations [47]. In the Bipindi-Akom II-Lolodorf region, south Cameroon, logging sites reached qualitative similarity values comparable to old growth forests after 14 years, and after 27 years, logged sites strongly resembled old growth forest sites. In shifting cultivation sites, recovery was generally slower but after 50-60 years most sites attained old growth values for most forest characteristics [48]. Recovery from different starting points thus can differ markedly.

Such patterns of recovery may differ in areas subject to geophysical disturbance such as cyclones and landslides. In the Solomon Islands canopy height has not recovered after 50 years in the logged forests of Kolombangara Island (Table 6). However, tree stand density became similar to that in unlogged forest after just 10 years. Sapling abundance in these forests was significantly higher than in unlogged forests because of the persistence of long-lived pioneers during succession [49]. This pattern of species coexistence usually occurs in forests subject to 
ongoing disturbances because of geological volatility and extreme weather [50, 51]. The occurrence of regular strong winds, sporadic earthquakes, and landslides on Kolombangara Island may have resulted in a succession whereby long-lived pioneers can persist.

Table 6. Indicators of forest recovery from disturbance from other parts of the world.

\begin{tabular}{|c|c|c|}
\hline Indicator type & Observations & Source \\
\hline $\begin{array}{l}\text { Biodiversity } \\
\text { Butterflies }\end{array}$ & $\begin{array}{l}\text { Responses to disturbance largely species-specific. Butterfly indicators } \\
\text { need to be taxonomically defined }\end{array}$ & {$[52]$} \\
\hline Avifauna & $\begin{array}{l}\text { Species richness or measures of overall abundance are not good } \\
\text { indicators of forest recovery }\end{array}$ & [52] \\
\hline Bats & $\begin{array}{l}\text { In bats in Trinidad: strong positive correlation between the number of } \\
\text { years since forest disturbance and the abundance of gleaning } \\
\text { animalivores, but not for frugivores or nectarivores }\end{array}$ & [53] \\
\hline Mammals & $\begin{array}{l}\text { Reduction or shifting of great ape densities } \\
\text { No significant drop in Bornean orangutan density after low intensity } \\
\text { logging, but marked drop under heavy logging. In Sumatra, orangutan } \\
\text { feeding time in the logged forest similar to that in the primary forest, but } \\
\text { more time spent moving around. }\end{array}$ & [54] \\
\hline Plants & $\begin{array}{l}\text { In Cameroon, logging sites have similar indicator values to old growth } \\
\text { forests after } 14 \text { years, but in shifting cultivation sites only after 50-60 } \\
\text { years } \\
\text { Total seedling density similar across logged and unlogged forest in } \\
\text { Amazonia case study } \\
\text { Average } 70 \% \text { of species richness recovered } 20 \text { years after end of shifting } \\
\text { cultivation in Amazonia } \\
\text { Species richness in logging gaps initially high, decreasing to be similar to } \\
\text { old growth forests after } 14 \text { years }\end{array}$ & $\begin{array}{l}{[45]} \\
{[55]} \\
{[48]}\end{array}$ \\
\hline $\begin{array}{l}\text { Decomposition of } \\
\text { woody debris }\end{array}$ & $\begin{array}{l}\text { Decomposition rates appear little affected by disturbance except in } \\
\text { extreme conditions where canopy opening results in drying of litter and } \\
\text { soil }\end{array}$ & [52] \\
\hline Canopy cover & Recovers within about 10 years & [52] \\
\hline Canopy height & Not recovered after up to 50 years, Solomon Islands & [49] \\
\hline Tree stand density & Saturation level after 10 years, Solomon Islands & [49] \\
\hline Tree size & Trees $\geq 30 \mathrm{~cm}$ Dbh found at 30 years of succession in Atlantic Forest Brazil & [46] \\
\hline Basal area & In many African forests, basal area may over than 100 years to recover & [47] \\
\hline $\begin{array}{l}\text { Environmental factors } \\
\text { Soil }\end{array}$ & $\begin{array}{l}\text { Soil C stocks varied little with logging in Amazonia } \\
\text { C:N ratio in litter increased systematically with time since logging } \\
\text { Loss of soil C, N and P from logging roads and log landing areas reduces } \\
\text { regrowth, Cameroon } \\
\text { Soil seed stock dominated by herbs and impact notable in early } \\
\text { succession in southern Cameroon } \\
\text { Need to critically examine effects of forestry activities on characteristics } \\
\text { like hydraulic conductivity at soil depths of over } 20 \mathrm{~cm} \\
\text { In Victoria, Australia, } 10 \text { years after logging bulk density of skid trail soils } \\
\text { was significantly greater and organic matter content and microporosity } \\
\text { significantly lower than in undisturbed forest }\end{array}$ & $\begin{array}{l}{[45]} \\
{[56]} \\
{[58]} \\
{[59]}\end{array}$ \\
\hline
\end{tabular}




\section{Animal behaviour post logging}

\section{Primates}

Logging affects population dynamics by reducing or shifting great ape densities within areas targeted by logging. Bornean orangutans do not see a significant drop in density after low intensity logging, but do so under heavy logging (Table 6). In Sumatra, orangutan feeding time in the logged forest remained similar to that in the primary forest, but time spent moving increased and time spent resting seemed to decrease. The increase in moving time seems to indicate that orangutan food sources were likely to be more scattered in the logged area. In the logged forest, orangutans may target specific trees during fruiting, probably pioneer species that yield bigger crops after logging. Orangutans were also found at a lower height in the logged forest than in the primary forest; this is most likely explained by the decrease in height of the trees in the logged forest [54].

\section{Bats}

Using bats as recovery indicators, there was no correlation between the number of years since forest disturbance and the abundance of frugivores, nectarivores and aerial insectivores. However, there was a strong positive correlation between the number of years since forest disturbance and the abundance of gleaning animalivores, indicating that the bat community recovers with forest regeneration [53].

\section{Importance of soil properties for rain forest recovery}

In southern Cameroon it was also noted that, as in other tropical rainforest sites, the soil seed bank is dominated by weedy and short-lived pioneer species which are light-demanders and could only emerge under adequate conditions, that is, in forest gaps. Thus, the contribution that soil seed stocks make to logged forest recovery may be notable in early stages of forest succession. Soil seed stocks are unlikely to be helpful for growth of major timber trees and consequently many foresters have used enrichment planting to achieve a possibly sustainable yield of timber in the future.

Varied opinions on soil chemical constituents occur (Table 6). Some show nutrient loses after logging, while others find little difference between logged and unlogged areas. The nutrient available in the litter layer are generally depleted during logging, but gradually revive as the forest biomass recovers. Soil properties are likely to vary with parent materials and across logged areas, depending on how much they have been compacted by logging traffic. The access roads and log landing areas that had heavy trucks moving over them frequently during timber harvesting will become severely compacted and take decades to recover.

\section{Discussion}

Recovery from disturbance in rainforests is as varied as the forests themselves. Some of the biota, such as birds and ants respond rapidly, but not uniformly. Some generalist species return rapidly, rainforest-dependent specialist species take much longer to populate regrowing forest patches and might be good indicators of forest recovery for biodiversity. Measures of species richness and diversity can be good general indicators, but there have to be considerations of factors such as distance of recovering areas from the undisturbed forest.

In this effort to achieve rainforest recovery, society is endeavouring to manage succession, a process that has been long-discussed, but without a deep understanding of the processes 
involved [60]. Even in closely studied landscapes with long ecological records, many of the most valued habitats are not "climax" communities, not pristine landscapes, but midsuccessional [61]. Rainforest recovery from disturbance is likely to be interrupted by natural drought, windthrow or landslides and by increased storminess and wildfire risk due to peopledriven climate change. Thus, even if there are reliable indicators of recovery, they will have to be evaluated with care to cope with spatial and temporal variations in growing conditions.

Recovery for future timber harvesting is readily done by assessing presence and growth of commercially valuable species, but there are lessons to be learned about the frequency of selective logging operations. In some areas rotations may be at 30 -year intervals, but if logging is to be sustainable, with constant yields intervals probably need to be more than 70 years. It is likely to be globally important to have some rainforest managed for timber production, but such forests must also be assessed for their multiple ecosystem services. The indicators used to assess post-logging recovery should include aspects of the fauna and flora. In addition, attention should be paid to the logging infrastructure, especially the roads and stream crossings. Once logging ceases these decay, cut and fill slopes erode and major storms send masses of sediment into streams, damaging fish habitats, affecting much aquatic life. Indicators related to soil properties are helpful in such assessments.

Recovery for the human enjoyment of nature depends on the appearance of the forest, which can be managed or constructed, nevertheless there are many people who value the opportunity to see wildlife in its natural habitat. People's impressions of what they thought of rainforests could provide indicators of forest recovery.

Recovery for wilderness seems almost a contradiction, but at a time when "rewilding" to some ill-defined vision of a past "wild" state, there seems to be no reason not to envisage an endeavour to assess recovery to a wilderness condition. Forests have invaded abandoned settlements and former goldmines over the centuries. The broad criteria for wilderness, minimum undisturbed core area, absence of current human interference and a minimum width of one day's walk could provide basic indicators. Many will seek indicators of genetic diversity, but the main concern may be conflicts in goals between potential users of a recovering forest.

\section{Conclusion}

Indicators of rainforest recovery can contribute to a more sustainable future for these magnificent ecosystems, but they need to be clearly defined and meaningful. Probably there will be different sets of indicators for the desired recovery endpoint. For example, if a National Park capable attracting visitors was the goal, the indicators might include measures of visitor satisfaction, while enabling traditional forest peoples to continue their hunting and gathering rights in the forest would include the viability of their communities and their hunting success as indicators. It might be possible to meet multiple goals in a recovering forest, but society and science ought to be realistic about their values and aims for rainforest recovery and its sustainable uses. 


\section{REFERENCES}

1. Thang, H.C. and Chappell, N.A. (2004) Minimising the hydrological impact of forest harvesting in Malaysia's rainforests, in Bonell, M. and Bruijnzeel, L.A. (eds) Forests, Water and People in the Humid Tropics, Cambridge: Cambridge University Press, 852865.

2. Webb L.J. (1958) Cyclones as an ecological factor in tropical lowland rain-forest, north Queensland, Australian Journal of Botany, 6: 220-230.

4. Crow, D.A. (1980) A Rainforest Chronicle: A 30-Year Record of Change in Structure and Composition at El Verde, Puerto Rico, Biotropica, 12 (1): 42-55.

4. Whitmore, T.C. (1974) Changes with time and the role of cyclones in tropical rain forest on Kolombangara, Solomon Islands, Commonwealth Forestry Institute Papers, 46.

5. Garcia-Florez, L., Vanclay, J.K., Glencross, K. and Nichols, J.D. (2017) Understanding 48 years of changes in tree diversity, dynamics and species responses since logging disturbance in a subtropical rainforest, Forest Ecology and Management, 393: 29-39.

6. Vanclay, J.K. (1990) Effects of selection logging on rainforest productivity, Australian Forestry, 53: 200-214.

7. Helman, P.M., Jones, A.D., Pigram, J.J. and Smith, J.M.B. (1976) Wilderness in Australia; Eastern New South Wales and South-eastern Queensland, Armidale: Department of Geography, University of New England.

8. Heckenberger, M. and Neves, E.G. (2009) Amazonian Archaeology, Annual Review of Anthropology, 38: 251-266.

9. Douglas, I. (1975) Pressures on Australian Rain-forests, Environmental Conservation, 2 (2): 109-119.

10. Horne, R. and Gwalter, J. (1987) The Recovery of Rainforest Overstorey Following Logging 2. Warm Temperate Rainforest, Forest Ecology and Management, 22: 267-281.

11. Kavanagh, R.P. and Stanton, M.A. (2005) Vertebrate species assemblages and species sensitivity to logging in the forests of north-eastern New South Wales, Forest Ecology and Management, 209 (3): 309-341, doi.org/10.1016/j.foreco.2005.02.009.

12. Cox, M.P., Dickman, C.R. and Hunter, J. (2003) Effects of rainforest fragmentation on nonflying mammals of the Eastern Dorrigo Plateau, Australia, Biological Conservation, 115: $175-189$.

13. Lemckert, F. (1999) Impacts of selective logging on frogs in a forested area of northern New South Wales, Biological Conservation, 89: 321-328.

14. Catterall, C.P. (2020) Values of weedy regrowth for rainforest restoration, Ecological Management and Restoration, 21 (1): 9-13.

15. Smith, R.G.B. and Nichols, J.D. (2005) Patterns of basal areas increment, mortality and recruitment were related to logging intensity in subtropical rainforest in Australia over 35 years, Forest Ecology and Management, 218 (1-3): 319-328.

16. Erskine, P.D., Catterall, C.P., Lamb, D. and Kanowski, J. (2007) Patterns and Processes of Old Field Reforestation in Australian Rain Forest Landscapes, In: Cramer, V.A. and Hobbs, R.J. (eds) Old Fields Dynamics and Restoration of Abandoned Farmland, Washington D.C.: Society for Ecological Restoration and Island Press, 119-144.

17. Anderson, A. (2004) Dairy Deregulation in Northern Queensland: The End of Traditional Farming? Anthropological Forum, 14 (3): 269-282, doi: 10.1080/0066467042000269521.

18. Sloan, S., Goosem, M. and Laurance, S.G. (2016) Tropical forest regeneration following land abandonment is driven by primary rainforest distribution in an old pastoral region, Landscape Ecology, 31: 601-618. 
19. Grimbacher, P.S. and Catterall, C.P. (2007) How much do site age, habitat structure and spatial isolation influence the restoration of rainforest beetle species assemblages? Biological Conservation, 135: 107-118.

20. Lawes, M.J., Moore, A.M., Andersen, A.N., Preece, N.D. and Franklin, D.C. (2017) Ants as ecological indicators of rainforest restoration: Community convergence and the development of an Ant Forest Indicator Index in the Australian wet tropics, Ecology and Evolution, 7: 8442-8455.

21. Catterall, C.P., Freeman, N.D., Kanowski, J. and Freebody, F. (2012) Can active restoration of tropical rainforest recue biodiversity? A case with bird community indicators, Biological Conservation, 146: 53-61.

22. Derhé, M.A., Murphy, H.T., Preece, N.D., Lawes, M.J. and Menéndez, R. (2018) Recovery of mammal diversity in tropical forests: a functional approach to measuring restoration, Restoration Ecology, 26 (4): 778-786.

23. Maggs, J. and Hewett, B. (1993) Organic C and nutrients in surface soils from some primary rainforests, derived grasslands and secondary rainforests on the Atherton Tableland in North East Queensland, Australian Journal of Soil Research, 31 (3): 343-50.

26. Hazebroek, H.P., Adlin, T.Z. and Sinun. W. (2012) Danum Valley: The Rain Forest, Kota Kinabalu: Natural History Publications (Borneo).

27. Hector, A., Fowler, D., Nussbaum, R., Weilenmann, M., and Walsh, R. (2011). The future of South East Asian rainforests in a changing landscape and climate. Philosophical Transactions of the Royal Society B: Biological Sciences, 366: (1582), 3165.

28. Hayward, R.M., Banin, L.F., Burslem, D.F.R.P., Chapman, D.S., Philipson, C.D., Cutler, M.E.J., Reynolds, G., Nilus, R. and Dent, D.H. (2021) Three decades of post-logging tree community recovery in naturally regenerating and actively restored dipterocarp forest in Borneo, Forest Ecology and Management, 488: 119036, https://doi.org/10.1016/j.foreco.2021.119036.

29. Abu Bakar, S.N. and Chappell, N.A. (n.d.) Long-term sediment recovery from a managed tropical forest catchment in Danum Valley, Sabah, Proceedings of the seminar on long term ecological

research, $\underline{\text { https://scholar.google.co.uk/scholar? cluster }=3097240585907180485 \& \text { hl=en\&as_sdt }=0,5 \mathrm{~S}}$ $\underline{\mathrm{N}}$

30. Walsh, R.P.D., Bidin, K., Blake, W.H., Clarke, M.A. Chappell, N.A., Douglas I., Ghazali, R., Sayer, A.M., Suhaimi J., Tych, W. and Annammala K.V. (2011) Long-term responses of rainforest erosional systems at different spatial scales to selective logging and climatic change, Philosophical Transactions Royal Society, London, B, 366: 3340-3353.

31. Kamaruzaman, J. (1996) Estimation of rate of recovery of disturbed soils from groundbased logging in peninsular Malaysia, Journal of Tropical Forest Science, 9: 88-100.

32. Malmer, A. and Grip, H. (1990) Soil disturbance and loss of infiltrability caused by mechanized and manual extraction of tropical rainforest in Sabah, Malaysia, Forest Ecology and Management, 38: 1-12.

33. Van der Plas, M.C. and Bruijnzeel, L.A. (1993) Impact of mechanized selective logging of rainforest on topsoil infiltrability in the Upper Segama areas, Sabah, Malaysia, IAHS Publication, 216: 203-211.

34. Ziegler, A.D., Negishi, J.N. Sidle, R.C., Gomi, T., Noguchi, S. and Nik, A.R. (2007) Persistence of road runoff generation in a logged catchment in Peninsular Malaysia, Earth Surface Processes and Landforms, 32: 1947-1970, DOI: 10.1002/esp.1508.

35. Edwards D.P., Edwards D.P., Magrach, A., Woodcock, P., Ji, Y., Lim, N.T-L., Edwards, F.A., Larsen, T.H., Hsu, W.W., Benedick, K.S., Chey, V.K., Chung, A.C., Reynolds, G., Fisher, B., Laurance, W.F., Wilcove, D.S., Hamer, K.C. and Yu, D.W. (2014) Selective- 
logging and oil palm: multitaxon impacts, biodiversity indicators, and trade-offs for conservation planning, Ecological Applications, 24 (8): 2029-2049.

36. Woodcock, P., Edwards D.P., Newton R.J., Chey, V.K., Bottrell, S.H. and Hamer, K.C. (2013) Impacts of intensive logging on the trophic organisation of ant communities in a biodiversity hotspot, PLOS ONE 8 (4): https://doi.org/10.1371/journal.pone.0060756.

37. Burghouts, T., Ernsting, G., Korthals, G. and De Vries, T. (1992) Litterfall, leaf litter decomposition and litter invertebrates in primary and selectively logged Dipterocarp forest in Sabah, Malaysia, Philosophical Transactions Royal Society: Biological Sciences, 335: 407-416.

38. Edwards D.P., Woodcock, P., Newton R.J., Edwards, F.A., Andrews, D.J.R., Docherty, T.D.S., Mitchell, S.L., Ota, T., Benedick, K.S., Bottrell, S.H. and Hamer, K.C. (2013) Trophic flexibility and the persistence of understory birds in intensively logged rainforest, Conservation Biology, 27: 1079-1086, https://doi.org/10.1111/cobi.12059.

39. Pinard, M.A., Barker, M.G. and Tay, J. (2000) Soil disturbance and post-logging forest recovery on bulldozer paths in Sabah, Malaysia, Forest Ecology and Management, 130 (13): 213-225, https://doi.org/10.1016/S0378-1127(99)00192-9..

40. Senior, R.A., Hill, J.K., Benedick, S. and Edwards, D.P. (2018) Tropical forests are thermally buffered despite intensive selective logging, Global Change Biology, 24:12671278, https://doi.org/10.1111/gcb.13914.

41. Annammala, K.V., Nainar, A., Yusoff, A.R.M., Yusop, Z., Bidin, K., Walsh, R.P.D., Blake, W.H., Abdullah, F., Sugumaran, D. and Pillay, K.G. (2018) Environmental Forensics: A Multi-catchment Approach to Detect Origin of Sediment Featuring Two Pilot Projects in Malaysia, Improving Flood Management, Prediction and Monitoring (Community, Environment and Disaster Risk Management, Vol. 20), Bingley: Emerald Publishing Limited: 49- 61, https://doi.org/10.1108/S2040-726220180000020013.

42. Annammala, K.V., Mohamad, N.A., Sugumaran, D., Masilamani, L.S., Liang, Y.Q., Jamal, M.H., Yusop, Z., Yusoff, A.R.M. and Nainar, A. (2021) Sediment clues in flood mitigation: the key to determining the origin, transport, and degree of heavy metal contamination, Hydrology Research, 52 (1): 91-106, doi: https://doi.org/10.2166/nh.2020.119.

43. Pinard, M.A. and Putz, F.E. (1996) Retaining forest biomass by reducing logging damage, Biotropica, 28: 278-295.

44. Edwards, D. P., Woodcock, P., Edwards, F. A., Larsen, T. H., Hsu, W. W., Benedick, S. and Wilcove, D. S. (2012) Reduced-impact logging and biodiversity conservation: A case study from Borneo. Ecological Applications, 22(2), 561-571.

45. Bomfim, B., Silva, L.C.R. Pereira, R.S., Gatto, A., Emmert, F. and Higuchi, N. (2020) Litter and soil biogeochemical parameters as indicators of sustainable logging in Central Amazonia, Science of the Total Environment, 714: 136780, https://doi.org/10.1016/j.scitotenv.2020.136780.

46. Zambiazi, D.C., Fantini, A.C., Piotto, D., Siminski, A., Vibrans, A.C., Oller, D.C., Piazza, G.E. and Peña-Claros, M. (2021) Timber stock recovery in a chronosequence of secondary forests in Southern Brazil: Adding value to restored landscapes, Forest Ecology and Management, 495: 119352, doi.org/10.1016/j.foreco.2021.119352.

47. Gourlet-Fleury, S., Mortier, F., Fayolle. A., Baya, F., Ouédraogo, D., Bénédet, F. and Picard, N. (2013) Tropical forest recovery from logging: a 24 year silvicultural experiment from Central Africa. Philosophical Transactions Royal Society: Biological Sciences 368: 0120302. http://dx.doi.org/10.1098/rstb.2012.0302

48. Van Gemerden, B.S., Shu, G.N. and Olff, H. (2003) Recovery of conservation values in Central African rain forest after logging and shifting cultivation, Biodiversity and Conservation 12: 1553-1570. 
49. Katovai, E., Katovai, D.D., Campbell, M., Laurance, S.G., Edwards, W. and Laurance, W.F. (2021) Structural Recovery of Logged Forests in the Solomon Islands: Implications for Conservation and Management, Tropical Conservation Science, 14: 1-13, doi: $10.1177 / 19400829211028125$.

50. Burslem, D.F.R.P., Whitmore, T.C. and Brown, G.C. (2001) Short-term effects of cyclone impact and long-term recovery of tropical rain forest on Kolombangara, Solomon Islands, Journal of Ecology, 88 (6): 1063-1078, doi.org/10.1046/j.1365-2745.2000.00517.x.

51.Whitmore, T.C. (1989) Canopy Gaps and the Two Major Groups of Forest Trees, Ecology, $70(3) ; 536-538$.

52. Ghazoul, J. and Hellier, M.A. (2000) Setting critical limits to ecological indicators of sustainable tropical forestry, International Forestry Review, 2 (4): 243-253.

53. Clarke, F.M., Rostant, L.V. and Racet, P.A. (2005) Life after logging: post-logging recovery of a neotropical bat community, Journal of Applied Ecology, 42: 409-420, doi: 10.1111/j.1365-2664.2005.01024.x.

54. Hardus, M.E., Lameira, A.R., Menken, S.B.J. and Wich, S.A. (2012) Effects of logging on orangutan behavior, Biological Conservation, 146: 177-187.

55. Villa, P.M., Martins, S.V., Neto, S.N.deO., Rodrigues, A.C., Safar, N.V.H., Monsanto, L.D., Cancio, N.M. and Ali, A. (2018) Woody species diversity as an indicator of the forest recovery after shifting cultivation disturbance in the northern Amazon, Ecological Indicators, 95 (1): 687-694, doi.org/10.1016/j.ecolind.2018.08.005.

56. Lontsi, R.T., Corre, M.D., van Straaten, O. and Veldkamp, E. (2019) Changes in soil organic carbon and nutrient stocks in conventional selective logging versus reduced-impact logging in rainforests on highly weathered soils in Southern Cameroon, Forest Ecology and Management, 451: 117522.

57. Dainou, K., Bauduin, A., Bourland, N., Gillet, J-F., Feteke, F. and Doucet, J-L. (2011) Soil seed bank characteristics in Cameroonian rainforests and implications for post-logging forest recovery, Ecological Engineering, 37: 1499-1506.

58. Lozano-Baez, S.E., Domínguez-Haydar, Y., Meli, P., van Meerveld, I, Vásquez, K. and Castellini, M. (2021) Key gaps in soil monitoring during forest restoration in Colombia Restoration Ecology, 29 (4): e13391.

59. Rab, M.A. (2004) Recovery of soil physical properties from compaction and soil profile disturbance caused by logging of native forest in Victorian Central Highlands, Australia, Forest Ecology and Management, 191: 329-340.

60. Wilson, J.B., Agnew, A.D.Q. and Roxborough, S.H. (2019) The nature of plants, Cambridge: Cambridge University Press.

61. Wilkinson, D.M. (2021) Ecology and natural history, London: Collins. 